\title{
Analysis of Transaction Capability in Gate In-2 Automation Export at PT Terminal Petikemas Surabaya uses Control Chart
}

\author{
Chairunissa Kusnoaji ${ }^{*}$, Iis Dewi Ratih ${ }^{1}$.
}

\begin{abstract}
PT Terminal Petikemas Surabaya is an international standard container terminal that always makes innovations to improve the quality of container export and import services. OCR is a container data identification tool that has begun to be used at the gate in the automation of exports of PT Terminal Petikemas Surabaya. The existence of OCR at the gate in export automation creates a new time motion for transactions that need to be known about the processing capabilities. Using the control chart $\bar{x}-S$ and Ishikawa diagram, it is found that the time motion transactions that occur at the gate in automation exports of PT Terminal Petikemas Surabaya are statistically out of control and incapable of being caused by many factors, both internal and external.
\end{abstract}

\section{Keywords - Container, Control chart, Gate, Time motion}

\section{INTRODUCTION}

$\mathrm{T}$ ERMINAL containers are one of the container transportation facilities that are in great demand by service users to ship goods between islands and export-import activities via sea. The role of container terminal functions includes container stacking service places and providing access to transportation for container loading and unloading activities. Especially in East Java, there is an international container terminal that has been trusted by many Indonesian and international companies in managing international containers, namely PT Terminal Petikemas Surabaya.

Carrying the status as an international container terminal, PT Terminal Petikemas Surabaya does not stop making breakthroughs with international standards. One of them is the operation of the gate in automation export using OCR to identify container data that will enter PT Terminal Petikemas Surabaya to be sent to the destination country. OCR is an application that functions to record container data images and make them into text. This innovation certainly gets more attention on how the impact created on the performance quality allowance for PT Terminal Petikemas Surabaya.

This is the basis of this research to analyze timemotion transactions carried out at the gate in automation export using the control chart $\bar{x}-S$ method. This control chart $\bar{x}-S$ method is used to determine whether the time motion process at the gate in automation export has been controlled statistically or not. And continued by using Ishikawa diagrams to find out the causes that affect if the time motion process at the gate in automation export has not been controlled. The results of this study are the average duration of activity 3 (Tally Input to Tally Confirm) during the low season is shorter than the average duration during the peak season. The data meet the assumptions of normal distribution, are randomly distributed, are not statistically controlled, and are not capable.

1 Department of Business Statistics, Faculty of Vocational Studies, Institut Teknologi Sepuluh Nopember, Kampus ITS Sukolilo, Surabaya 60111, Indonesia. E-mail: suyati03yusi@gmail.com
The limitation of the problem in this study is the direct observation on shift 3, namely 16.00 - 23.00 WIB because it is assumed to be the shift that has the most transaction activities compared to shifts 1 and 2 . Observations are made at the gate in 2 because it is assumed that the location is the most strategic and is always open. For export container entry gate at PT. Terminal Petikemas Surabaya so most transaction activities are carried out. Observational data is taken as much as $\pm 80 \%$ from the total transactions during 16.00 - 23.00 WIB because $\pm 20 \%$ the data that cannot be retrieved is assumed that the researcher is praying, eating, going to the toilet, and missing information.

\section{A. PT Terminal Petikemas Surabaya}

PT Terminal Petikemas Surabaya, as a world-class standard terminal in Indonesia, is committed to maintaining a unique and prominent position of TPS, namely as a Gateway to the Eastern Indonesian Region, to ensure that the company can provide the quality services needed to support Indonesia's economic growth and to provide the best service for customers. With the company's motto, Reliable Terminal with Service Excellence, customer satisfaction is TPS's top priority.

Vision PT Terminal Petikemas Surabaya as a worldclass standard terminal in Indonesia, is committed to maintaining the position of PT Terminal Petikemas Surabaya is unique and stands out as the Gateway to the Eastern Indonesia Region, to ensure that the company can provide the quality services needed to support Indonesia's economic growth and to provide the best service for its customers. With the company motto, Reliable Terminal with Service Excellence, customer satisfaction is PT Terminal Petikemas Surabaya.

The mission of PT Terminal Petikemas Surabaya is to become a company that is progressive, responsive, trustworthy, providing container terminal facilities that can meet all demands for both domestic and international trade for all trading communities in eastern Indonesia [1].

\section{B. Peak Season and Low Season in Export}

Export activity is a trading system through removing goods from within the country and abroad by complying 
with applicable regulations. Exports are the total goods and services sold by a country to another country, including goods, insurance, and services in a certain year [2].

Peak season or in Indonesian means the high season used as a term at the gate at PT Terminal Petikemas Surabaya which means the peak of transactions at the gate. Meanwhile, low season is used to mean that transactions are quiet or few at the gate. But at PT Terminal Petikemas Surabaya, there is no written standard regarding the number of container transactions that can be said to be entered at the peak season or low season, so the researchers assume that transactions can be said to be a peak season when there is no queueing delay between trucks. Likewise, on the contrary, transactions that can be said to be low season are when there is a delay or a long distance between truck transactions from one another.

\section{The Activity 1 - 3}

Activity 1 is Portal In - Driver Tapping RF-ID. The definition of the first activity or movement starts from the portal in which is near the opening security post, drivers who have been checked for RF-ID by security are welcome to enter the gate at a stable speed without stopping in the middle of the road and are allowed to stop behind the out portal with the position of the head truck next to it Kios-K to simplify the RF-ID tapping driver. Then the driver will get visual instructions on the monitor to tap the RF-ID accompanied by the sound "Welcome to Terminal Petikemas Surabaya, insert your driver's identity card". This process is said to be complete when the driver has taped the RF-ID and it can be ascertained that the driver is correct in tapping the RF-ID when a "beep" sound is heard from Kios-K which is then followed by a visual notification on the monitor and a sound "please wait, your transaction being processed".

Activity 2 is Driver Tapping RF-ID - Tally Start Input. The definition of the second activity or movement starts when the driver has finished tapping the RF-ID and gets a visual notification on the monitor and a sound "please wait, your transaction is being processed". The system will link the information that has been obtained by OCR to the HHT (Hand Held Terminal) device held by the tally (the officer who checks the seal number, the physical container, and the police number of the container transporting truck.) This process is said to be complete when the container data has been entered. HHT and tally input police numbers, while the driver gets notifications and instructions on the monitor and a voice "waiting for the tally to verify the seal number".

Activity 3 is Tally Start Input - Tally Confirm. The definition of the third activity or movement begins when the container data has entered the HHT and the tally enters the police number, while the driver gets notifications and instructions on the monitor and a voice "waiting for the tally to verify the seal number". Then tally checks the physical container starting from the container number, ISO, MGW, seal number, whether there is damage or not, and does a heavy refresh. The process is said to be complete when the tally clicks the "confirm" option on HHT.

\section{Activity 4-6}

Activity 4 is Tally Confirm - Job Slip Out. The definition of the fourth activity or movement starts when the tally has finished inputting data and clicking the "confirm" option on the HHT. Then the system will link the physical information about the container to the Kios$\mathrm{K}$. This process is said to be completed when the job slip has been successfully printed and leaves the Kios-K. There are two possible types of job slips that will be accepted by the driver, if there is a data mismatch, the driver will get a job slip containing an order to contact the officer in the exception area and a visual command on the monitor followed by a voice "please meet the officer in the exception area". Meanwhile, if all the data is in accordance, then the job slip that will be received by the driver contains a container stacking block and a notification on the monitor followed by a sound "please go to the block (according to the plot yard plan)".

Activity 5 is Job Slip Out - Truck Leave. The definition of the fifth activity or movement begins when the job slip comes out along with the opening of the dividing portal between the gate and the container yard. This process is said to be complete when the head truck has passed the sensor after the portal will automatically open the portal so that the next truck can enter the gate.

Activity 6 is Portal In - Truck Leave. The definition of this sixth activity or movement is a combination of the first activity to the fifth activity consecutively, which starts from gate in-2 near the open security post, drivers who have been checked for RF-ID by security are welcome to enter the gate at a stable speed without stopping in the middle of the road and allowed to stop behind the out portal with the head truck position next to the Kios-K to facilitate RF-ID tapping drivers. This process is said to be complete when the head truck has passed the sensor after the portal which will automatically open the portal so that the next truck can enter the gate.

\section{E. Time Motion Study}

Time and motion study can be defined as an approach that directs engineering in having a method related to designing a work station that is desired either by the designer or by the company [3].

The technique of measuring time and motion study directly by observing directly the work done by the operator and recording the time required by the operator to do his job by first dividing the work operation into work elements as detailed as possible on the condition that it can still be observed and measured. The method of direct measurement can now use the stopwatch time study and work sampling [4].

\section{METHOD}

\section{A. Histogram}

A histogram is a bar chart that shows a tabulation of data organized by size. This tabulation of data is commonly known as a frequency distribution. The histogram shows the characteristics of the data which are divided into classes. The $\mathrm{x}$-axis frequency histogram shows the observed value of each class. The histogram is in "normal" or bell form indicating that much of the data 
is in average. The histogram shape that is slanted or asymmetrical shows a lot of data that is not in the average value, but the value is in the upper or lower limit [5].

\section{B. Randomness Test}

The randomness test or run test is a test that functions to find out whether the data has been taken randomly. One important example of that is when we will perform a statistical analysis of some available sample data. If the randomness of a sample is in doubt, we would want to have a way of getting to the analysis stage. Many other situations may make us want to investigate the assumptions that have been made about the randomness of the samples concerned [6].

Hypothesis:

$\mathrm{H}_{0}$ : Observational data have been taken randomly from a population

$\mathrm{H}_{1}$ : Observational data are not taken randomly from a population

The statistical test is $r$, namely the number of sequences that occur. Reject any $\mathrm{H}_{0}$ if $\mathrm{r}<\mathrm{r}$ is lower or $\mathrm{r}>\mathrm{r}$ is above from the critical value table for the series $r$ with $n_{1}$ and $n_{2}$ where:

$\mathrm{n}_{1}$ is the number of data marked 'plus' (+)

$\mathrm{n}_{2}$ is the number of data marked 'minus' (-)

If $\mathrm{n}_{1}$ or $\mathrm{n}_{2}>20$, the formula used is shown in equation 1 :

$$
z=\frac{r-\left\{\left(2 n_{1} n_{2}\right) /\left(n_{1}+n_{2}\right)+1\right\}}{\sqrt{2 n_{1} n_{2}\left(2 n_{1} n_{2}-n_{1}-n_{2}\right)\left(n_{1}+n_{2}\right)^{2}\left(n_{1}+n_{2}-1\right)}}
$$

The $\mathrm{z}$-value is compared with the standard normal distribution value. the assumptions of the parametric statistical analysis were not fulfilled [6].

\section{Normality Test}

Checking the assumptions of normally distributed residuals is used to detect the normality of the residuals. The assumption of the normal distribution can be seen by looking at the plot, if the plot follows and approaches a linear line then the data is normally distributed and if the plot does not follow and away from the linear line then the data is not normally distributed. The assumption of a normal distribution can also be determined using the Kolmogorov Smirnov test, namely by comparing the cumulative normal distribution function of the normal $\left\{\mathrm{F}_{0}(\mathrm{x})\right\}$ distribution with the empirical distribution function of the sample $\left\{S_{n}(x)\right\}$. The hypothesis of this test is as follows.

Hypothesis:

$\mathrm{H}_{0}: \mathrm{F}(\mathrm{x})=\mathrm{F}_{0}(\mathrm{x})$ for all $\mathrm{x}$ values

$\mathrm{H}_{1}: \mathrm{F}(\mathrm{x}) \neq \mathrm{F}_{0}(\mathrm{x})$ for at least one $\mathrm{x}$ value

Rejection Area: Reject $\mathrm{H}_{0}$ if $|\mathrm{D}|>\mathrm{D}_{(\alpha ; \mathrm{n})}$ or $\mathrm{P}_{\text {value }}<\alpha$

Test statistic is shown by equation 2 :

Information:

$$
D=\sup |S(x)-F 0(x)|
$$

$S_{n} \quad$ : The cumulative probability function of the sample data

$\mathrm{F}_{0}(\mathrm{x}) \quad$ : Normal cumulative distribution function

D : Supremum all $x$ of value $\left|S_{n}(x)-F_{0}(x)\right|$

\section{Variable Control Chart $\bar{x}-S$}

The control chart $\bar{x}-S$ s a variable control chart used in controlling the process mean (a measure of accuracy) and standard deviation (a measure of precision). Compared to maps, $\bar{x}-R$ charts, $\bar{x}-S$ charts are more sensitive in detecting process changes for large sample sizes $(>10)$.

Just like the control chart, only to create control limits, it is necessary to estimate the standard deviation with the standard deviation method. Given $s_{1}, S_{2}, \ldots, S_{m}$ is the standard deviation of $\mathrm{m}$ samples, represented by equation 3 .

$$
\bar{s}=\frac{s_{1}+s_{2}+\ldots+s_{m}}{m}
$$

Then the control limit for the control chart can be shown in equation 4 .

$$
\begin{aligned}
& B K A=\overline{\bar{x}}+A_{3} \bar{s} \\
& G T=\overline{\bar{x}} \\
& B K B=\overline{\bar{x}}-A_{3} \bar{s}
\end{aligned}
$$

Information:

$\overline{\bar{x}} \quad$ : average value

$\bar{s} \quad:$ the standard deviation of the mean

BKA : upper control limit on the control chart

GT : central control limit on a control chart

BKB : lower control limit on a control chart

$\mathrm{A}_{3} \quad$ : constants in the variable control chart table

Process diversity is monitored by plotting the value of the sample standard deviation on the control chart with control boundaries such as equation 5 .

Information:

$B_{3}$ : Constants in the variable control chart table

$B_{4}$ : Constants in the variable control chart table .

\section{E. Ishikawa}

This diagram is often called a fishbone diagram developed by a Japanese person named Kaoru Ishikawa, so it is often referred to as the Ishikawa diagram or often referred to as a fishbone diagram. A fishbone diagram is a diagram that is used to show the causes and effects caused by those causative factors.

\section{F. Sources Data}

Sources of data used in this study are primary data obtained directly. This data collection was carried out on Sunday, February 23, 2020 - Saturday, March 7, 2020, at the export gate in- 2 of PT Terminal Petikemas Surabaya at $16.00-23.00 \mathrm{WIB}$.

\section{G. Research Variable}

The research variable used in this study is to use the duration or time motion of the gate in export automation transactions with the ratio data scale. Divided into several activity elements, namely portal in - driver tap RF-ID, driver tap RF-ID - Tally start input, Tally start input - Tally confirm, tally confirm - job slip out, job slip out - truck leaves, the portal in - truck leave.

\section{H. Analysis Steps}

The analysis steps carried out in this study are.

1. Collecting time-motion data for gate in-2 export automation transactions at PT Terminal Petikemas Surabaya. 
2. Exploring time-motion data for gate in-2 export automation transactions at PT Terminal Petikemas Surabaya.

3. Analysis of the time motion processing capability for the gate in-2 export automation transaction at PT Terminal Petikemas Surabaya.

a. Normality test on time-motion data for gate in-2 export automation transactions at PT Terminal Petikemas Surabaya.

b. Control chart of $\mathrm{S}$ time-motion transaction gate in-2 export automation at PT Terminal Petikemas Surabaya.

4. Identifying the cause of the discrepancy in the time motion transaction gate in-2 export automation at PT Terminal Petikemas Surabaya using the Ishikawa diagram.

5. Make conclusions and suggestions.

\section{RESULT AND DISCUSSION}

Discussion on the results of the analysis in the form of exploration of time motion data for the gate in-2 export automation transaction at PT Terminal Petikemas Surabaya, followed by a control chart $\bar{x}-S$ and with Ishikawa diagrams to determine the cause of the transaction is not capable. The analysis results that will be displayed are.

\section{A. Exploration of Time Motion Transaction Gate In-2 Automation Export.}

The results of the time motion data for the export automation gate in-2 transaction at PT Terminal Petikemas Surabaya can be described in several parts as follows.

\section{Average Transaction Every Activity in Every Day.}

The average time motion for export automation gate in-2 transactions at PT Terminal Petikemas Surabaya per activity per day can be seen in Figure 1 .

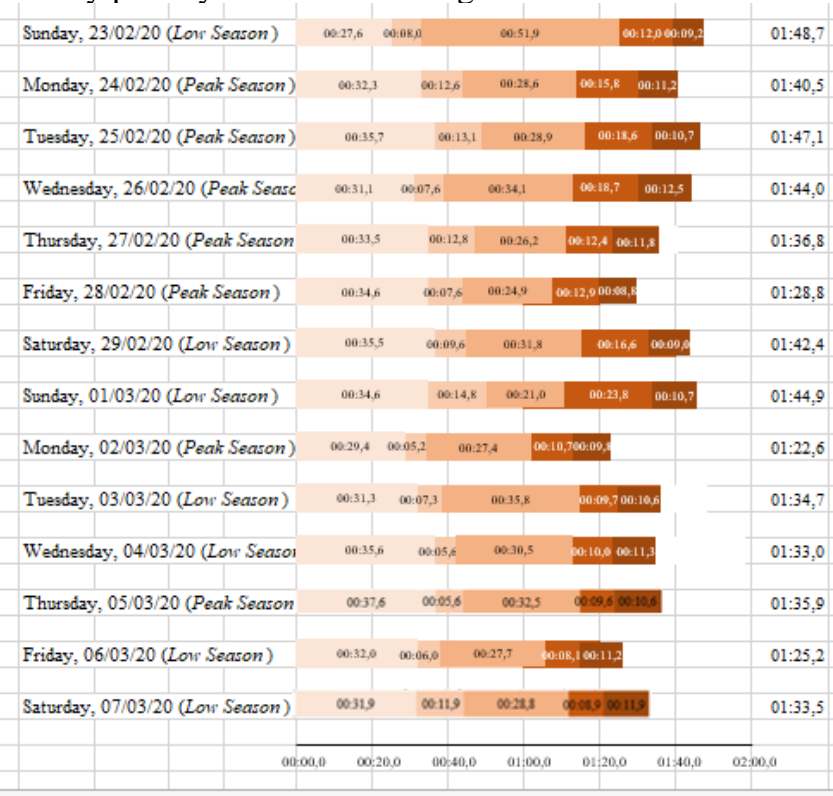

Figure 1. Average Transaction Every Activity (February 23, 2020 March 07, 2020).

Figure 1. Shows that:

a. Sunday, February 23, 2020, of 30 transactions, the longest average duration was in activity 3 (Tally
Input to Tally Confirm), which was 51.9 seconds. So that the total average duration of the entire transaction or the average duration of activity 6 (Portal In to Truck Leave) is 1 minute 48.7 seconds.

b. Monday, February 24, 2020, from 172 transactions, the longest average duration was activity 1 (Portal In - Driver tap RF-ID), which was 32.3 seconds.

c. Tuesday, February 25, 2020, out of 186 transactions, the average with the shortest duration was activity 5 (Job slip out-Truck Leave), which was 10.7 seconds.

d. Wednesday, February 26, 2020, of 147 transactions, the average with the shortest duration was activity 2 (Driver tap RF-ID - Tally Input), which was 07.6 seconds.

e. Thursday, February 272020 from 198 transactions, the average duration of activity 4 (Tally confirm Job slip out) is 12.4 seconds.

f. Friday, February 28, 2020, out of 208 transactions, the longest average duration was activity 1 (Portal In - Driver tap RF-ID) which was 34.6 seconds.

g. Saturday, February 29, 2020, from 167 transactions, the longest average duration was activity 1 (Portal In - Driver tap RF-ID) which was 35.5 seconds.

h. Sunday, March 1, 2020, of 45 transactions, the shortest average duration is activity 5 (Job slip outTruck Leave), which is 10.7 seconds.

i. Monday, March 2, 2020, out of 233 transactions, the average with the shortest duration was activity 2 (Driver tap RF-ID - Tally Input), which was 5.2 seconds.

j. Tuesday, March 3, 2020, of 142 transactions, the longest average duration was in activity 2 (Tally input-Tally Confirm), which was 35.8 seconds.

k. Wednesday, March 4, 2020, of 215 transactions, the average duration of activity 5 (Job slip out-Truck Leave) is 11.3 seconds.

1. Thursday, March 5, 2020, from 204 transactions, the average with the shortest duration was in activity 2 (Driver tap RF-ID - Tally Input), which was 5.6 seconds.

m. Friday, March 6, 2020, of 191 transactions, the average duration of all transactions or the average duration of activities to 6 (Portal In to Truck Leave) is 1 minute 25.2 seconds.

n. Saturday, March 7, 2020, from 123 transactions, the average duration of the entire transaction or the average duration of the 6 activity (Portal In to Truck Leave) is 1 minute 33.5 seconds.

\section{Average Transaction at February 23, 2020 -March 07, 2020}

The average time motion for export automation gate in-2 transactions at PT Terminal Petikemas Surabaya on February 23, 2020 - March 07, 2020, from 2261 transactions can be seen in Figure 2. which shows that the average with the shortest duration is activity 2 (Driver tap RF-ID - Tally Input) which is 9.4 seconds. While the longest average duration was activity 1 (Portal In - Driver tap RF-ID) was 33.1 seconds. So that the total average duration of the entire transaction or the average 
duration of activity 6 (Portal In to Truck Leave) is 1 minute 37 seconds.

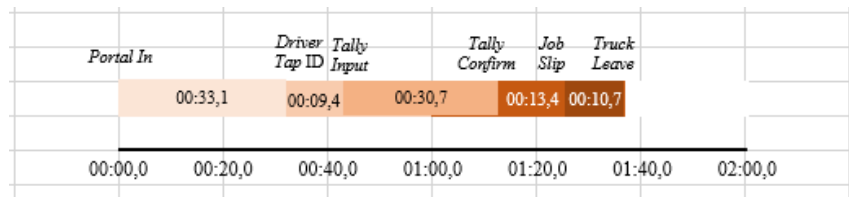

Figure 2. Average Transaction February 23, 2020 - March 07, 2020.

\section{Average Transaction Every Activity In Low Season and Peak Season.}

The average time motion for gate in-2 export automation transactions at PT Terminal Petikemas Surabaya in the low season of 913 transactions can be seen in Figure 3. which shows that the average with the shortest duration is activity 2 (Driver tap RF-ID - Tally Input) which is 9 seconds. So that the total average duration of the entire transaction or the average duration of activity 6 (Portal In to Truck Leave) is 1 minute 37.5 seconds.

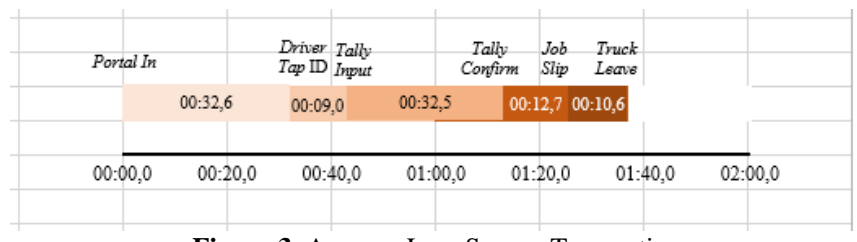

Figure 3. Average Low Season Transaction.

The average time motion for gate in-2 export automation transactions at PT Terminal Petikemas Surabaya during the peak season of 1348 transactions can be seen in Figure 4. which shows that the average with the shortest duration is activity 2 (Driver tap RF-ID - Tally Input) which is 9.2 seconds. So that the total average duration of the entire transaction or the average duration of activity 6 (Portal In to Truck Leave) is 1 minute 36.5 seconds.

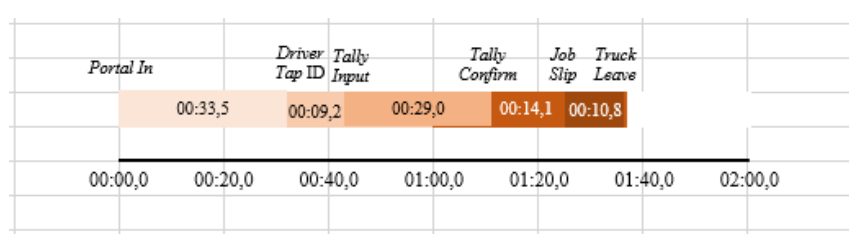

Figure 4. Average Peak Season Transaction.

\section{Average Transaction Every Day On February 23,} 2020-March 07, 2020.

The average time-motion for export automation gate in-2 transactions at PT Terminal Petikemas Surabaya per day on February 23, 2020 - March 07, 2020, can be seen in Figure 5.
$04: 19,2$
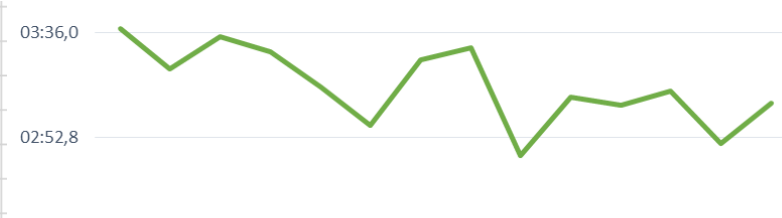

02:09,6

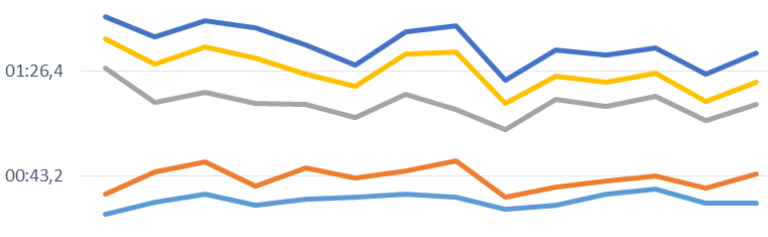

00:00,0

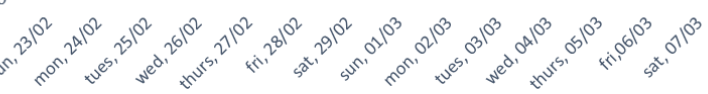

CPortal In-Driver Tap ID D Driver Tap ID - Tally Input

—Tally Input - Tally Confirm _ Tally Confirm - Job Slip Ou

Job Slip Out-Truck Leave —Portal In-Truck Leave

Figure 5. Average Duration of Activities.

Figure 5. shows that:

a. The average activity 1 (Portal In - Driver tap RF-ID) for 14 days was 33.1 seconds.

b. The average activity 2 (Driver tap RF-ID - Tally Input) for 14 days was 9.4 seconds.

c. The average activity 3 (Tally input-Tally Confirm) for 14 days was 30.7 seconds.

d. The average of activity 4 (Tally confirm - Job slip out) for 14 days is 13.4 seconds.

e. The average activity 5 (Job slip out-Truck Leave) for 14 days is 10.7 seconds.

f. The average activity 6 (Portal In to Truck Leave) for 14 days is 1 minute 37 seconds.

5. Average Duration of each Activity Season.

The average time motion for export automation gate in-2 transactions at PT Terminal Petikemas Surabaya each season on February 23, 2020 - March 07, 2020, can be seen in Figure 6.

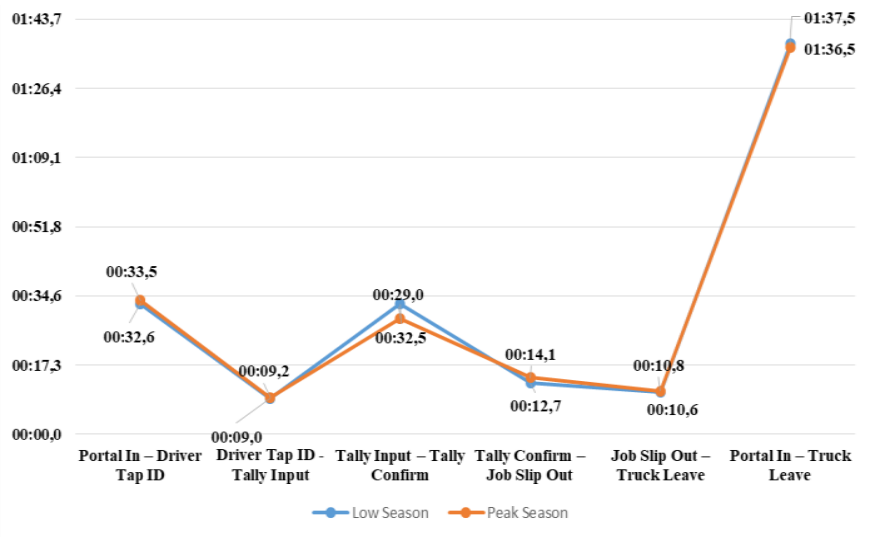

Figure 6. Average Duration of Activities every Season.

Figure 6. shows that:

a. The average duration of activity 1 (Portal In - Driver tap RF-ID) during low season and peak season only has a difference of 0.9 seconds. 
b. The average duration of activity 2 (Driver tap RF-ID Tally Input) during low season and peak season is only 0.2 seconds difference.

c. The average duration of activity 3 (Tally input-Tally Confirm) during the low season is longer than the peak season with a difference of 3.5 seconds.

d. The average duration of activity 4 (Tally confirm Job slip out) during low season and peak season is only 1.4 seconds difference.

e. The average duration of activity 5 (Job slip out-Truck Leave) during the low season and peak season is only 0.2 seconds apart.

f. The average duration of activity 6 (Portal In to Truck Leave) during low season and peak season is the only 1 seconds difference.

B. Transaction Process Analysis on February 23, 2020 - March 07, 2020.

The data exploration above shows that the average overall activity (Portal In - Truck Leave) during the low season is longer than the peak season which is known to be caused by activity 3 (Tally Input - Tally Confirm). Therefore, activity 3 requires an analysis of the time motion process for export automation gate in-2 transactions at PT Terminal Petikemas Surabaya on February 23, 2020 - March 7, 2020, from 2261 transactions as follows.

\section{Control Chart $\bar{x}-S$ Capability Analysis.}

Process capability analysis using a control chart $\bar{x}-S$ because can measure the level of accuracy of a process as follows.

\section{a. Normal Distribution Assumption Test.}

Hypothesis :

$\mathrm{H}_{0}$ : Time motion transaction gate in-2 automation export at PT Terminal Petikemas Surabaya normally distributed.

$\mathrm{H}_{1}$ : Time motion transaction gate in-2 automation export at PT Terminal Petikemas Surabaya not normally distributed.

With a significant level of $\alpha$ of 0,05 the rejection area is obtained, namely reject $\mathrm{H}_{0}$ if $|\mathrm{D}|>\mathrm{D}_{\text {tabel Kolmogorov Sminorv }}$ $(1-\alpha ; \mathrm{n})$ or $p$-value $<0,05$.

TABLE 1.

NORMAL DISTRIBUTION ASSUMPTION TEST

\begin{tabular}{ccc}
\hline \hline KS & KS table & P-Value \\
\hline 0,133 & 0,029 & 0,01 \\
\hline \hline
\end{tabular}

Table 1. shows that the Kolmogorov Smirnov value is 0.133 which is greater than the KS table of 0.029 supported by a p-value of 0.01 where less than 0.05 , the $\mathrm{H}_{0}$ decision is rejected, which means that the time motion data for the gate in-2 transaction export automation at PT Terminal Petikemas Surabaya is not normally distributed.

\section{b. Randomness Test}

The results of the randomization test analysis based on the average per day are shown in the following table form.
Hypothesis:

$\mathrm{H}_{0}$ : The average time motion for gate in-2 export automation transactions at PT Terminal Petikemas Surabaya has been randomly distributed.

$\mathrm{H}_{1}$ : Average time motion for gate in transactions-2 export automation at PT Terminal Petikemas Surabaya is not randomly distributed.

With a significant level of $\alpha$ of 0.05 , the rejection area is obtained, namely rejecting $\mathrm{H}_{0}$ if $\mathrm{r}<\mathrm{r}$ is lower or $\mathrm{r}>\mathrm{r}$ is above and p-value $<0.05$. Test Statistics:

TABLE 2.

\begin{tabular}{ccc}
\multicolumn{3}{c}{ RANDOMNESS TEST } \\
\hline \hline $\mathrm{r}$ & $\mathrm{R}$ above & P-Value \\
\hline 9 & 7,43 & 0,338 \\
\hline \hline
\end{tabular}

Table 2. shows that the $r$ is obtained of 9 where more than $r$ is below 7.43 and is supported by a p-value of 0.338 where more than 0.05 , the decision to Fail to Reject $\mathrm{H}_{0}$ is obtained, which means that the average time motion of the gate in-2 transaction the export automation at PT Terminal Petikemas Surabaya has been randomly distributed.

\section{c. Process Analysis Using a Control Chart $\bar{x}-S$.}

The normal distribution assumption test, which is a requirement for making control charts, has found that the data do not meet the normal distribution assumptions. But to find out whether the map is controlled or not, it is assumed that the process is normally distributed so that it can be seen with the control chart $\mathrm{S}$ as follows.

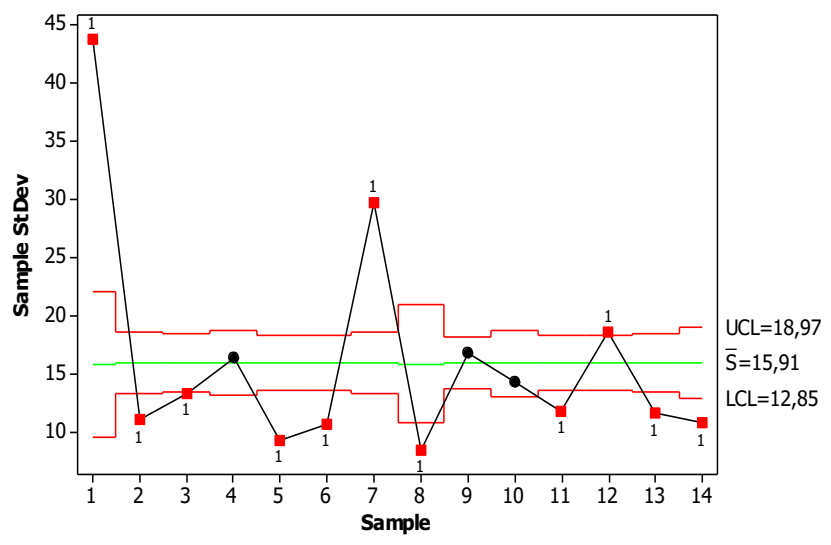

Figure 7. Control Chart $\mathrm{S}$

Figure 7. shows that there are plots that are beyond the upper control limit of 18.97 seconds on Sunday, February 23, 2020, Saturday, February 29, 2020, and Thursday, March 5, 2020, so it can be concluded that the time motion for the gate in-2 export automation transaction is PT Terminal Petikemas Surabaya is not statistically controlled. Because the $\mathrm{S}$ control chart is out of control, it cannot be continued with the control chart analysis $\bar{x}$.

\section{Ishikawa Transaction Activity 3.}

Ishikawa time-motion gate-in-2 export automation transactions at PT Terminal Petikemas Surabaya, activity 3 (Tally Input - Tally Confirm) on February 23, February 29, and March 5, 2020, can be seen in Figure 8. as follows. 




Figure 9. Ishikawa time-motion transaction gate in-2 automation export.

Analysis using Ishikawa is carried out when a process is out of control or does not meet the capabilities of the process. The cause of the time motion for the gate in-2 export automation transaction at PT Terminal Petikemas Surabaya on February 23, February 27, and March 5, 2020, was influenced by the material or condition of trucks and containers, work procedures, tally, and machines or tools used for data input.

\section{CONCLUSION}

The average duration of the whole activity (Portal In to Truck Leave) during the low season is longer than the average duration during the peak season. This is caused by the third activity during the Tally Input - Tally Confirmation. The process analysis results show that the time motion data for the gate in-2 export automation transaction at PT Terminal Petikemas Surabaya in the third activity does not fulfill the normal distribution assumption, but it is assumed to be normally distributed to see the control chart which shows that activity III is not statistically controlled. So that in fact, the formation of a control chart cannot be done. Analysis using Ishikawa found that the effect that causes the process to be uncontrollable is influenced by the conditions of trucks and containers, work procedures, tally, and machines or tools.

Suggestions for PT Terminal Petikemas Surabaya are to pay more attention to the time motion duration of the gate in export automation transactions by educating or socializing with Tally and paying more attention to system performance and HHT so that errors or very long data loading do not occur frequently. As well as giving an appeal to drivers, forwarders, and workers at the gate regarding the rules that apply to transactions at the gate.

\section{REFERENCES}

[1] Y. P. Utomo, "Ekspor Mendorong Pertumbuhan atau Pertumbuhan Mendorong Ekspor", Jurnal Manajemen, Vol.1, No.1, UII. Yogyakarta. 2000.

[2] Wignjosoebroto,. "Ergonomi Studi Gerak dan Waktu Teknik Analisis untuk Peningkatan Produktivitas Kerja". Surabaya : PT. Guna Wijaya. 1995.

[3] R. Prihantoro,. "Konsep Pengendalian Mutu". Bandung: Remaja Rosdakarya. 2012

[4] W. W. Daniel, "Statistika Nonparametrik Terapan". Jakarta: Gramedia. 1998.

[5] Sudjana.. "Metode Statistika". Bandung: Tarsito. 2005
[6] D. C Montgomery, "Introduction to Statistical" Quality Control. United States of America: John Wiley \& Sons, Inc. 2009.

[7] V. Gaspersz, "Total Quality Management". Jakarta: PT. Gramedia Pustaka Utama. 2005. 